\title{
Amicitia et seditio. \\ Conflictstructuren in de ontwikkeling van de stedelijke autonomie in Sint-Truiden tijdens de eerste helft van de twaalfde eeuw*
}

\author{
Ewoud WAERNIERS \\ Universiteit Gent
}

Vanaf de elfde eeuw werden heel wat vroege stedelijke gemeenschappen, in het bijzonder in Noord- en Centraal-Italië en Noordwest-Europa, gekenmerkt door processen van politieke emancipatie. Stedelingen verbonden zich hierbij in eedgenootschappen, die vaak communio, coniuratio of conspiratio werden genoemd. De bronnen die ons informeren over deze hang naar autonomie zijn vaak beladen met narratieven over geweld en rebellie. Toch leken de stedelingen zelf zowel interne vrede binnen de stad als vredevolle relaties met externe machthebbers voor ogen te hebben. De stadsbewoners legitimeerden hun eedverbonden immers op grond van religieus geconnoteerde idealen zoals fraternitas, caritas, concordia, amicitia en $\operatorname{pax}^{(1)}$. De contradictie tussen hoe de stedelingen enerzijds zelf beweerden te handelen in de geest van waarden als eendracht en broederschap en anderzijds als goddeloze geweldplegers werden gepercipieerd door de kerkelijke auteurs uit hun tijd, wordt door Otto Gerhard Oexle de "paradox of conspiracy", genoemd: hoewel deze organisaties hun bestaansrecht op universele waarden schraagden, hadden hun acties hoofdzakelijk tot doel de eigen leden van het eedgenootschap te begunstigen, wat bij buitenstaanders onbegrip en tegenkantingen teweeg bracht ${ }^{(2)}$.

* Mijn dank gaat uit naar Jeroen Deploige, Jan Dumolyn, Jeff Rider en Jelle Haemers voor hun raad en opmerkingen. Dit artikel kwam tot stand in het kader van het project "Perception and Performance of Social Identity in the Nascent Urban Societies of the High Middle Ages" (Fonds Wetenschappelijk Onderzoek-Vlaanderen).

(1) Hagen Keller, "Die Entstehung der italienischen Stadtkommunen als Problem der Sozialgeschichte", in Frühmittelalterliche Studien, dl. 10, 1976, p. 194-196 en 203205; Knut Schulz, "Denn sie lieben die Freiheit so sehr...". Kommunale Aufstände und Entstehung des europäischen Bürgertums im Hochmittelalter, Darmstadt, Wissenschaftliche Buchgesellschaft, 1995, p. 5-13; Otto Gerhard OEXLE, "Peace Through Conspiracy", in Bernhard Jussen, ed., Ordering Medieval Society. Perspectives on Intellectual and Practical Modes of Shaping Social Relations, Philadelphia, University of Pennsylvania Press, 2001, p. 285-304 en Albert VermeESCH, Essai sur les origines et la signification de la commune dans le nord de la France (XI et XII siècles), Heule, UGA, 1966 (Études présentées à la Commission internationale pour l'Histoire des Assemblées d'États, 30), p. 175-183.

(2) O.G. OEXLE, "Peace Through Conspiracy", op. cit., p. 304-307. In een eerdere Duitse versie van zijn studie gebruikt Oexle de term "Verschwörung" voor het Engelse "conspiracy" (zie Otto Gerhard OEXLE, "Friede durch Verschwörung", in Johannes 
In dit artikel onderzoek ik op welke wijze een vroege stedelijke gemeenschap in haar ontwikkeling werd gekenmerkt door opeenvolgende fasen van conflict en verzoening. Het conflictueuze karakter van de middeleeuwse stedelijke emancipatiebeweging heeft al op heel wat aandacht kunnen rekenen van specialisten zoals bijvoorbeeld Otto Gerhard Oexle en Knut Schulz. De effectieve mechanismen en strategieën van het conflictverloop in zulke stedelijke autonomiseringsprocessen zijn nog heel wat minder onderzocht ${ }^{(3)}$. Toch is de middeleeuwse conflictbeheersing een studiegebied dat al sinds de jaren 1970 een hoge vlucht heeft genomen, vooral in het werk van antropologisch georiënteerde historici zoals Fredric Cheyette, Stephen White, Patrick Geary en Gerd Althoff ${ }^{(4)}$. Het merendeel van deze onderzoekers heeft echter vooral gefocust op geschillen tussen religieuze instellingen en regionale lekenheren in een rurale context ${ }^{(5)}$. Specifiek en inspirerend aan hun benadering is dat zij conflicten niet zien als losstaande gebeurtenissen, maar als schakels in lange processen van al dan niet gewelddadige, continue negotiaties van maatschappelijke posities en relaties. Patrick Geary bijvoorbeeld, kent conflicten als dusdanig een constructieve rol toe in het dagelijkse leven van de volle middeleeuwen: ze reguleerden de regionale machtsverhoudingen in een context waarin staatsgezag ontbrak en lagen aan de basis van de sociale cohesie van groepen ${ }^{(6)}$.

FRIED, ed., Träger und Instrumentarien der Friede im hohen und späten Mittelalter, Sigmaringen, Thorbecke, 1996, p. 115-150). De betekenis van de Latijnse termen voor dergelijke bondgenootschappen (coniuratio, conspiratio) is op zich al dubbelzinnig. Enerzijds leggen deze termen de nadruk op de eensgezindheid en samenhorigheid, die via het zweren van wederzijdse eden kon worden bereikt, maar anderzijds dragen ze ook de negatieve connotatie met zich mee van een subversief gegeven. In de ogen van de betrokkenen primeert met andere woorden het gevoel van beëdigde overeenstemming, terwijl tegenstanders de negatieve bijklank van het complot laten doorwegen. Deze semantische dubbelzinnigheid in de Latijnse terminologie weerspiegelt dus al de "paradox of conspiracy".

(3) O.G. OeXle, "Peace through conspiracy", op. cit., p. 285-322 en K. Schulz, "Denn sie lieben", op. cit. Een uitzondering vormt in dat opzicht de studie Alain SAINTDENIS, "La violence dans les villes du Nord de la France 1050-1150", in Benoît GARNOT, ed., Histoire et criminalité de l'Antiquité au XXe siècle. Nouvelles approches, Dijon, Éditions universitaires de Dijon, 1992, p. 257-264.

(4) Fredric CheyetTe, "Suum cuique tribuere", in French Historical Studies, dl. 6, 1976, 3, p. 287-299; Fredric CheyetTE, "Some Reflections on Violence, Reconciliation, and the "Feudal Revolution"", in Warren Brown \& Piotr GoRECKI, eds., Conflict in Medieval Europe. Changing Perspectives on Society and Culture, Aldershot, Ashgate, 2003, p. 243-264; Stephen D. WhITE, Feuding and Peace-making in Eleventh-Century France, Aldershot, Ashgate, 2005, p. 320; Patrick GEARY, "Living with Conflicts in Stateless France: a Typology of Conflict Management Mechanisms, 1050-1200", in Patrick GEARY, ed., Living with the Dead in the Middle Ages, Ithaca, Cornell University Press, 1994, p. 125-160 en Gerd Althoff, Spielregeln der Politik im Mittelalter, Darmstadt, Wissenschaftliche Buchgesellschaft, 1997, p. 360. Voor een overzicht van deze benadering van de middeleeuwse conflicten: Warren BROWN \& Piotr GORECKI, "What Conflict Means: the Making of Medieval Conflict Studies in the United States, 1970-2000", in W. BrowN \& P. GoRECKI, eds., Conflict in Medieval Europe, op. cit., p. 1-36.

(5) Een uitzondering hierop vormt Geoffrey KOzIOL, "Baldwin VII of Flanders and the Toll of Saint-Vaast (1111): Judgment as Ritual", in W. Brown \& P. GorECKI, eds., Conflict in Medieval Europe, op. cit., p. 151-161.

(6) P. GEARY, "Living with Conflicts", op. cit., p. 136-160. 
Dit artikel wil middels een casestudy over Sint-Truiden in de eerste helft van de twaalfde eeuw nagaan hoe relaties van vriendschap en conflict functioneerden binnen een verstedelijkingsproces. De nederzetting van SintTruiden - ontstaan rond een zevende-eeuwse benedictijnenabdij - groeide vanaf de elfde eeuw uit tot een kleine $\operatorname{stad}^{(7)}$. Sint-Truiden hield omstreeks 1100 het midden tussen grotere bisschopssteden zoals Luik of Keulen en kleine, louter landelijke nederzettingen. Dat blijkt onder meer uit het woordgebruik in de vroeg-twaalfde-eeuwse bronnen zelf, waarin Sint-Truiden consequent een oppidum wordt genoemd in tegenstelling tot enerzijds kleinere nederzettingen en anderzijds grotere (bisschops)steden, die respectievelijk als villae en civitates of urbes worden getypeerd ${ }^{(8)}$. Bij de aanvang van de twaalfde eeuw bestonden er in Sint-Truiden evenwel nog geen sterk ontwikkelde communale instituties, noch hadden de stadsbewoners grote vrijheden verkregen. Sint-Truiden bleef in de elfde en vroege twaalfde eeuw, hoewel omgord door een omwalling en opgedeeld in verschillende parochies, een bescheiden centrum. Ook vanuit die optiek wil deze bijdrage een leemte vullen, aangezien in het onderzoek naar de stedelijke emancipatie tijdens de volle middeleeuwen de aandacht - zeker voor wat Noordwest-Europa betreft - haast steeds is uitgegaan naar grotere bisschopssteden of bloeiende handelscentra, waar vaak al vrij vroeg privileges en communale instituties werden afgedwongen. ${ }^{(9)}$ Weliswaar beschikten de inwoners van Sint-Truiden in het midden van de twaalfde eeuw over enkele vrijheden $^{(10)}$, maar de eerste neergeschreven sporen van een instelling die de

(7) Rodulfus Trudonensis, Gesta abbatum Trudonensium I-VII. Accedunt epistulae, ed. Paul Tombeur, Turnhout, Brepols, 2013 (Corpus Christianorum Continuatio Mediaevalis, 257), p. 13-18. Zie ook Jean-Léon ChARLES, La ville de Saint-Trond au Moyen Âge. Des origines à la fin du XIVe siècle, Parijs, Les Belles Lettres, 1965 (Bibliothèque de la Faculté de Philosophie et Lettres de l'Université de Liège, 95), p. 126-129 en 154-155 en Stephanie HAARLÄNDER, "Kloster und Stadt Sint Truiden zur Zeit des Abtes Rudolf (1108-1138)", in Alfred HAVERKAMP \& Frank G. HiRSCHMANN, eds., GrundherrschaftKirche-Stadt zwischen Maas und Rhein während des hohen Mittelalters, Mainz, Verlag Philipp van Zabern, 1997, p. 186-189.

(8) Rodulfus Trudonensis, Gesta abbatum Trudonensium, ed. TOMBEuR, op. cit., libri I-VII. Sint-Truiden wordt bijvoorbeeld als oppidum nostrum beschreven, terwijl de nederzettingen in de omgeving villae worden genoemd in dezelfde passage (p. 18). Wanneer later Luik aan bod komt heeft men het over de civitas (bijvoorbeeld op p. 50). Een gelijksoortig hiërarchisch onderscheid tussen villa, oppidum en urbs merkt Ludo Milis op bij Guibert de Nogent: Ludo MiLis, "Monks, Canons, and the City: A Barren Relationship?", in The Journal of Interdisciplinary History, dl. 32, 2002, 4, p. 678.

(9) Recent onderzocht Paulo Charruadas de vroege stadsontwikkeling van Brussel. Deze stad was net als Sint-Truiden tijdens de volle middeleeuwen een eerder bescheiden nederzetting: Paulo CHARRUADAS, Croissance rurale et essor urbain à Bruxelles. Les dynamiques d'une société entre ville et campagnes (1000-1300), Brussel, Académie royale de Belgique, 2011 (Mémoires de la Classe des Lettres, vol. 56, nr. 2074).

(10) In 1140 bevestigde Stefaan van Bar, de bisschop van Metz, een tolvrijheid aan de Truienaars: Charles PIOT, Cartulaire de l'abbaye de Saint-Trond, dl. 1, Brussel, Hayez, 1870 (Académie royale de Belgique. Commission royale d'Histoire. Collection de chroniques belges inédites, 42), p. 55-56. De bisschop van Luik, Hendrik van Leyen, beperkte op zijn beurt de rechterlijke macht van de bisschoppen van Luik ten opzichte van de Truienaars in 1146: Stanislas Bormans \& Mathieu Lambert Polain, Recueil des ordonnances de la principauté de Liége, dl. 1, Brussel, Gobbaerts, 1855, dl. 1, p. 17-18. Godefroid Kurth brengt dit privilege in verband met het tweede artikel van het charter dat in 1208 aan de Luikenaars wordt toegekend. Als Kurths hypothese klopt dan houdt 
stedelijke gemeenschap van Sint-Truiden vertegenwoordigde, vinden we pas terug in een oorkonde daterend uit 1227 van bisschop Hugo II van Pierrepont, die dat jaar de heerlijkheid van Sint-Truiden verwierf van de bisschop van Metz. Hierin bevestigde Hugo de rechten die onder meer de gezworenen (iurati) en alle stedelingen (burgenses) voordien al genoten ${ }^{(11)}$. De gezworenen - een soort vertegenwoordigers van de gemeente, met juridische bevoegdheden bestonden dus al voor 1227. In Luik en Hoei ontwikkelde deze instelling zich vermoedelijk gedurende de tweede helft van de twaalfde en het begin van de dertiende eeuw ${ }^{(12)}$. Mogelijk geldt dit ook voor Sint-Truiden, maar we beschikken niet over schriftelijk bewijs dat dit bevestigt. Over schepenen te Sint-Truiden bestaan er wel al vroegere bronnen, maar deze schepenbanken functioneerden in de twaalfde eeuw duidelijk nog als heerlijke instellingen ${ }^{(13)}$.

Dit artikel focust in het bijzonder op de relaties en conflicten tussen de stedelijke elites, de lokale abdijgemeenschap van Sint-Truiden en de regionale feodale machthebbers tijdens de regeerperiodes van de abten Rodulf (11081138) en Folkard (1138-1145). De verkiezing van Rodulf sloot een turbulente abtsstrijd van bijna een kwarteeuw af, waarin zes pretendenten de abbatiale macht in de nederzetting naar zich toe hadden proberen te trekken en de stedelingen voor het eerst nadrukkelijk op de voorgrond waren getreden ${ }^{(14)}$. Over het wedervaren van Sint-Truiden onder Rodulf en Folkard zijn we hoofdzakelijk ingelicht dankzij de eerste en tweede continuatio van de Gesta abbatum Trudonensium. De eerste zeven boeken van deze kloosterkroniek schreef Rudolf zelf omstreeks 1114-1115. Diens eigen abbatiaat werd vervolgens omstreeks 1136 te boek gesteld in de eerste continuatio door Giselbert, de custos van de abdij. Als vertrouweling van abt Rodulf geeft Giselbert de verwezen-

het privilege in dat de inwoners van Sint-Truiden niet door de bisschoppelijke macht van Luik kunnen gedagvaard of geëxcommuniceerd worden, tenzij door een uitspraak van de synodale raad: Godefroid KURTH, "Les origines de la commune de Liège", in Bulletin de l'Institut archéologique liégeois, dl. 35, 1905, p. 236-237.

(11) Édouard PONCELET, ed., Actes des princes-évèques de Liège: Hugues de Pierrepont 1200-1229, Brussel, Paleis der Academiën, 1941, p. 232-233. Zie ook J.-L. CHARLES, La ville, op. cit., p. 375-377.

(12) Over de iurati en commune van Luik: Alfred HANSAY, "Notes sur la Cité de Liège au $\mathrm{XII}^{\mathrm{e}}$ siècle", in Mélanges Camille de Borman. Receuil de Mémoires relatifs à l'histoire, à l'archéologie et à la philologie, Luik, Imprimerie H. Vaillant-Carmanne, 1919, p. 101-106, G. KURTH, "Les origines", op. cit., p. 230-324 en Godefroid KURTH, La cité de Liège au Moyen-Âge, dl. 1, Brussel, Dewit, 1910, p. 92-109. Over de iurati en de commune van Hoei: André JoRIS, La ville de Huy au Moyen Âge. Des origines à la fin du XIV siècle, Parijs, Les Belles Lettres, 1959, p. 425-431. Het bronmateriaal over de Truiense iurati is ook voor het vervolg van de dertiende eeuw schaars. In de tweede helft van de dertiende en in de veertiende eeuw wordt er in Sint-Truiden verschillende keren een commune (communitas) opgericht, afwisselend bestuurd door patriciërs dan wel ambachtslieden en in grote mate onder controle van de prinsbisschoppen van Luik en/of de abten van Sint-Truiden. Zie ook J.-L. ChARLES, La ville, op. cit., p. 293-317 en 375-377.

(13) De schepen (scabini sancti Stephani sancti que Trudonis) worden voor het eerst vermeld als getuigen in een oorkonde van 1108: in Ch. PIOT, Cartulaire de l'abbaye, op. cit., p. 33-34. Zie ook J.-L. ChARlES, La ville, op. cit., p. 366-368.

(14) Over de rol van de stadsbevolking in de abtsstrijd: Rudi KüNZEL, Beelden en zelfbeelden van middeleeuwse mensen. Historisch-antropologische studies over groepsculturen in de Nederlanden, $7^{\text {de }}-13^{\text {de }}$ eeuw, Nijmegen, SUN, 1997, p. 159-169. 
lijkingen van zijn abt op een erg betrokken en dus gekleurde wijze weer(15). De anonieme tweede voortzetter van de Gesta schreef aan het eind van de twaalfde eeuw een verslag van de gebeurtenissen onder abt Folkard. In tegenstelling tot de eigentijdse beschrijvingen door Giselbert was er in het geval van de tweede continuatio dus een veel grotere kloof tussen de gebeurtenissen en hun te rapportering ${ }^{(16)}$. Voorts bieden ook de eerste zeven boeken van de Gesta abbatum Trudonensium, handelend over de abdijgeschiedenis tot 1108, en het rijke diplomatische bronnenmateriaal over Sint-Truiden, belangrijke informatie voor deze analyse ${ }^{(17)}$.

\section{Actoren in de conflictontwikkeling}

Sint-Truiden mocht dan wel gelegen zijn binnen het bisdom Luik, waardoor de abdij op spiritueel vlak gehoorzaamheid aan de Luikse bisschop verschuldigd was, de oorspronkelijke abdijnederzetting behoorde sinds de vroege middeleeuwen tot het Fernbesitz van de bisschoppen van Metz. Tegen de volle middeleeuwen viel Sint-Truiden evenwel uiteen in twee heerlijkheden. Het noordwesten van de stad behoorde toe aan de abt, terwijl het zuidoosten onder het temporele gezag van de bisschop van Metz was blijven staan. Abt en bisschop waren onder meer verantwoordelijk voor de heerlijke jurisdictie en het onderhoud van wegen, omwallingen en grachten binnen hun heerlijkheid. Door hun fysieke aanwezigheid mag men veronderstellen dat de directe invloed van de abten op de Truiense samenleving groter was dan die van de bisschoppen. De abdij had heel wat grondbezit in Sint-Truiden en omgeving en het merendeel van de inwoners bevond zich op enigerlei wijze in een afhankelijkheidsrelatie ten opzichte van de abt. Daarenboven gingen de inkomsten van de belastingen op het brouwen van bier in de volledige nederzetting sinds de eerste helft van de elfde eeuw naar de abt ${ }^{(18)}$. Naast de abten en de bisschoppen van Metz, hadden ook de abdijvoogden een grote invloed. Zij ontfermden zich over de hoge rechtspraak in de hele stedelijke nederzetting. De titel van voogd of advocatus was in de eerste helft van de twaalfde eeuw in handen van de graven van Limburg. Zij besteedden deze taak op hun beurt uit aan onder-

(15) Paul Tombeur, "Un nouveau nom de la littérature médiolatine: Gislebert de Saint-Trond", in Cahiers de Civilisation médiévale, d1. 10, 1967, p. 435-446.

(16) "Gesta abbatum Trudonensium (continuatio secunda)", in Jeroen DePloIGE, ed., The Narrative Sources from the Medieval Low Countries (Koninklijke Commissie voor Geschiedenis, 2009), www.narrative-sources.com, geraadpleegd op 18 april 2015, ID G057-R115. Voor het werk van Gislebert maak ik gebruik van de recente uitgave van Paul Tombeur: Gislebertus TRudonensis \& Rodulfus TRUdonensis, Gesta abbatum Trudonensium VIII-XIII, Turnhout, Brepols, 2013 (Corpus Christianorum Continuatio Mediaevalis, 257A). Voor de tweede anonieme continuatio en de latere continuationes gebruik ik Camille De Borman, Chronique de l'abbaye de Saint-Trond, dl. 2, Luik, Grandmont-Donders, 1877.

(17) De meeste oorkonden met betrekking tot Sint-Truiden in de volle middeleeuwen zijn te vinden in Ch. PIOT, Cartulaire de l'abbaye, op. cit.

(18) J.-L. CHARLES, La ville, op. cit., p. 84-89 en 331-346 en Eberhard LinCK, Sozialer Wandel in klösterlichen Grundherrschaften des 11. bis 13. Jahrhunderts, Göttingen, Vandenhoeck \& Ruprecht, 1979, p. 116-117. 
voogden, met name de heren van Duras, die een klein graafschap bezaten ten westen van de $\operatorname{stad}^{(19)}$.

Verschillende andere machthebbers trachtten eveneens hun invloed op de Sint-Truidense stadsgemeenschap te laten gelden. Dat geldt in de eerste plaats voor de bisschoppen van Luik, die zich omwille van hun spirituele autoriteit over de stad in tal van ontwikkelingen en conflicten hebben gemanifesteerd. Voorts poogden vanuit oostelijke richting de heren van Loon vaste voet in Sint-Truiden te krijgen en vanuit het westen de graven van Leuven ${ }^{(20)}$. Deze laatsten richtten in de twaalfde eeuw hun pijlen meermaals op Sint-Truiden, dat vlakbij de grens van hun graafschap en meer bepaald hun nederzetting Zoutleeuw was gelegen. Zij hadden hier meerdere redenen toe. Ten eerste stond de titel van hertog van Neder-Lotharingen op het spel, die zowel door de graven van Leuven als van Limburg werd geclaimd. Wilden de graven van Leuven hun aspiraties als hertogen van Neder-Lotharingen hard maken, dan moesten ze zich op hun oostelijke grensgebieden richten, waar Sint-Truiden de eerste stad was die bovendien onder voogdij stond van hun rivaal, de graaf van Limburg. Een tweede motivatie die traditioneel wordt ingeroepen, is dat de heren van Leuven ernaar streefden om vat te krijgen op het netwerk van handelsroutes tussen Keulen en Brugge, waarop Sint-Truiden gelegen was ${ }^{(21)}$. Een laatste reden kan gezocht worden in de grote rivaliteit die heerste tussen de Leuvense graven en Luikse prinsbisschoppen. De graven wensten immers de macht van Luik in hun graafschap te beperken ${ }^{(22)}$. Door Sint-Truidens strategische ligging raakte de stedelijke bevolking verzeild in wisselende allianties met de machthebbers en de kloostergemeenschap.

De eigenlijke bewoners van Sint-Truiden worden in de bronnen oppidani genoemd $^{(23)}$. Hun nauwe band met de abdij blijkt onder meer uit het feit dat de auteurs van de Gesta hen doorgaans als oppidani nostri omschreven. Vele stedelingen behoorden tot de familia sancti Trudonis, de verzamelnaam voor diegenen die op enigerlei wijze in een afhankelijkheidsrelatie stonden ten opzichte van de abdij. Dit behelsde een heterogene groep. Onderaan de ladder

(19) J.-L. Charles, La ville, op. cit., p. 347-358 en Constant LeClère, Les avoués de Saint-Trond, Leuven, Typographie C. Peeters, 1902. Over de voogden van Sint-Truiden en hun conflicten met de abdij in de elfde en de eerste helft van de twaalfde eeuw, zie ook Christian DuPONT, "Violence et avouerie au $\mathrm{XI}^{\mathrm{e}}$ et au début du XII ${ }^{\mathrm{e}}$ siècle en Basse-Lotharingie: note sur l'histoire des abbayes de Saint-Hubert et de Saint-Trond", in L'avouerie en Lotharingie, Luxembourg, Section historique de l'Institut grand-ducal de Luxembourg, 1984, p. 115-128.

(20) Jean BAERTEN, Het graafschap Loon (11 de $-14^{\text {de }}$ eeuw). Ontstaan-politiekinstellingen, Assen, Van Gorcum, 1989, p. 35-37 en 40-44.

(21) Over deze handelsroute: Paul BonENFAnT, "L'origine des villes brabançonnes et la "route" de Bruges à Cologne", in Belgisch Tijdschrift voor Filologie en Geschiedenis, dl. 31, 1953, 2, p. 399-447.

(22) Piet Avonds, "Brabant en Limburg 1100-1403", in Dirk P. BLoK, ed., Algemene Geschiedenis der Nederlanden, dl. 2, Haarlem, 1982, p. 452-482 en Jean BAERTEN, "Luik en Loon 1100-1390", in D.P. BLOK, ed., Algemene Geschiedenis, op. cit., dl. 2, p. 483-498.

(23) Rodulfus Trudonensis, Gesta abbatum Trudonensium, ed. cit., libri I-VII en Gislebertus TRUDONENSIS, Gesta abbatum Trudonensium, continuatio prima, ed. cit., libri VIII-XIII. Zie ook J.-L. ChARLES, La ville, op. cit., p. 143-144 en R. KüNZEL, Beelden en zelfbeelden, op. cit., p. 158. 
stonden de gewone horigen, al blijkt uit recent onderzoek van Alexis Wilkin dat de abdijeconomie al vrij vroeg niet alleen op traditionele horige diensten draaide, maar er ook heel wat geprebendeerde arbeidskrachten in dienst waren, vermoedelijk kleine vrije boeren die tegen betaling werkten, hetzij in natura, hetzij in munt. De precieze afhankelijkheidsrelatie tussen deze personen en de abdij is moeilijk in te schatten ${ }^{(24)}$. Eberhard Linck onderscheidt binnen de familia van Sint-Truiden vervolgens twee geprivilegieerde groepen: enerzijds de censuales, meestal vrijgewijden of horigen die door derden aan het klooster waren geschonken, en anderzijds de lokale elite ${ }^{(25)}$. Het is vooral die elite die in de stedelijke conflicten de hoofdrol speelde. Deze lieden worden in de Gesta zowel de meliores of maiores de familia genoemd als de meliores oppidani $^{(26)}$. Wie precies deel uitmaakte van deze elite, wordt nergens expliciet aangegeven ${ }^{(27)}$. Wellicht gaat het onder meer om de bestuurders van de landgoederen van de abdij (villici), de personen die een belangrijke rol speelden in de hofhouding van de abdij - zoals de seneschalk (dapifer), die belast was met economisch-financiële taken, en de kamerheer (camerarius) - en de personen die in naam van de abdij belastingen inden zoals de gruiter (grutarius) en de tollenaar (thelonearius) ${ }^{(28)}$. Wanneer, vanaf de tweede helft van de elfde eeuw, leden van de familia als getuigen opdoken in de oorkonden van de abdij, kwamen ze uit deze kringen. Vanaf het begin van de twaalfde eeuw worden velen van deze getuigen bovendien schepenen (scabini) genoemd ${ }^{(29)}$. Aangezien Sint-Truiden voor de helft toebehoorde aan de bisschop van Metz en voor de andere helft aan de abt van Sint-Truiden, waren er, op zijn minst vanaf 1108 , twee schepenbanken van zeven personen ${ }^{(30)}$. Daarnaast waren er ook twee rechters of schouten (iudices of scoltheti) ${ }^{(31)}$. Van verschillende leden

(24) Alexis WiLkin, “Corvée ou salariat? Contribution à l'histoire des structures foncières en Basse-Lotharingie au début du second millénaire par l'exemple des domaines centraux de l'abbaye de Saint-Trond", in Alexis WILKIN \& Jean-Louis KUPPER, eds., Évêque et prince, Notger et la Basse-Lotharingie aux alentours de l'an Mil, Luik, Presses universitaires de Liège, 2013, p. 129-145.

(25) E. Linck, Sozialer Wandel, op. cit., p. 116-146.

(26) Rodulfus TRUdonensis, Gesta abbatum Trudonensium, ed. cit., p. 32, 34 en 95 en Gislebertus TRUdOnEnsis, Gesta abbatum Trudonensium, continuatio prima, ed. cit., p. 59. Zie ook R. KÜNZEL, Beelden en zelfbeelden, op. cit., p. 158.

(27) J.-L. Charles, La ville, op. cit., p. 283-285. Zie ook S. HAARlÄNDER, "Kloster und Stadt", op. cit., p. 184-187; R. KÜNZEL, Beelden en zelfbeelden, op. cit., p. 158 en E. LiNCK, Sozialer Wandel, op. cit., p. 121-124 en 178-179.

(28) Meer informatie over de ambten van villicus, grutarius en thelonearius vindt men in Julien MAQUET, "Faire justice" dans le diocèse de Liège au Moyen Âge (VIII ${ }^{e}$-XII siècles). Essai de droit judiciaire reconstitué, Genève, Droz, 2008, p. 381-398.

(29) Op basis van gelijkenissen in het aantal en in de naamgeving van de getuigenlijsten in oorkonden uit de late elfde eeuw en het begin van de twaalfde eeuw vermoedt Charles dat deze schepenbanken zich reeds in de elfde eeuw aan het ontwikkelen waren: J.-L. CHARLeS, La ville, op. cit., p. 366-368.

(30) Ch. PIot, Cartulaire de l'abbaye, op. cit., dl. 1, nr. 23, p. 33-34. Zie ook J.-L. Charles, La ville, op. cit., p. 361-374 en E. LincK, Sozialer Wandel, op. cit., p. 128-138.

(31) Meer informatie over het ambt van iudex en over de verhouding tussen dit ambt en dat van villicus vindt men in J. MAQUET, "Faire justice", op. cit., p. 372-380 en E. LINCK, Sozialer Wandel, op. cit., p. 128-138. 
van deze elite is geweten dat ze allodiale grond of een leengoed (beneficium of feodum) bezaten ${ }^{(32)}$.

De elite kon zich dus zowel politiek als economisch van de rest van de SintTruidense bevolking onderscheiden. Ze had bovendien de reputatie bedreven te zijn in het paardrijden ${ }^{(33)}$ en de oorlogsvoering. Zo vertelt Rodulf dat het in Sint-Truiden nooit "aan een menigte van oorlogszuchtige en stoutmoedige mannen" ontbrak ${ }^{(34)}$. Deze reputatie zien we ook bevestigd in het historiografische werk van Gislebert van Bergen, die op het eind van de twaalfde eeuw de Truienaars nog steeds omschrijft als "rijke lieden en zeer bekwaam in hun omgang met wapens"(35).

Diegenen die tot de stedelijke elite van Sint-Truiden behoorden, waren als lid van de familia niettemin in zekere mate juridisch afhankelijk van de ab$\mathrm{dij}^{(36)}$. In de secundaire literatuur worden ze daarom doorgaans ministerialen genoemd $^{(37)}$. Knut Schulz betoogde dat dergelijke ministerialen, die hun sociale positie te danken hadden aan hun gunstige dienstrelatie met de lokale feodale machthebbers, een belangrijke rol hebben gespeeld in het ontstaan van zelfbewuste, stedelijke bevolkingsgroepen in het Duitse Koninkrijk ${ }^{(38)}$. De Truiense elite beantwoordde inderdaad aan het moderne rechtshistorische concept "ministeriaal"(39). Toch is dit woordgebruik enigszins problematisch, aangezien de term in geen enkele bron uit de elfde of twaalfde eeuw gebruikt wordt om personen uit de Truiense elite te benoemen. De monastieke geschiedschrijvers uit Sint-Truiden gebruikten weliswaar de term ministerialis, maar verwezen met dit woord naar voorname dienaren of vazallen van bisschoppen of van de keizer, die duidelijk een hogere positie bekleedden binnen

(32) Rodulfus TRUdonensis, Gesta abbatum Trudonensium, ed. cit., p. 20-28; Gesta abbatum Trudonensium, continuatio secunda, ed. cit., dl. 2, p. 24-25 en Ch. PIOT, Cartulaire de l'abbaye, op. cit., d1. 1, nr. 37, p. 47-48, en nr. 49, p. 65-66.

(33) GiSleBertus TRUdonensis, Gesta abbatum Trudonensium, continuatio prima, ed. cit., p. 10-11.

(34) Eigen vertaling, Rodulfus TRUdonensis, Gesta abbatum Trudonensium, ed. cit., p. 35: multitudine maxima bellicosorum magne, que audacie, virorum.

(35) Eigen vertaling, GisleberTus MonTEnsis, Chronicon Hanoniense, ed. Wilhelm ARNDT, Hannover, Hahn, 1869 (Monumenta Germaniae Historica, Scriptores, 21), p. 567: hominibus divitibus et in armis potentissimis.

(36) Een interessante studie van een prototypische vertegenwoordiger van de SintTruidense aristocratie vindt men in Rudi KÜNZEL, "Zo sprak Guntramnus. Het geschiedbeeld van een twaalfde-eeuwse stedeling”, in J.B. BERNS, ed., Feestbundel aangeboden aan prof. dr. D.P. Blok, Hilversum, Verloren, 1990, p. 204-215.

(37) J.-L. ChARLES, La ville, op. cit., p. 283-285; François-Louis GANSHOF, Étude sur les ministeriales en Flandre et en Lotharingie, Brussel, Lamertin, 1926, p. 167-177 en R. KüNZEL, "Zo sprak", op. cit., p. 211.

(38) Knut Schulz, "Die Ministerialität als Problem der Stadtgeschichte. Einige allgemeine Bemerkungen, erläutert am Beispiel der Stadt Worms", in Rheinische Vierteljahrsblätter, dl. 32, 1968, p. 184-219 en Knut SCHULZ, "Ministerialität und Bürgertum. Rückblick und Bewertung nach vierzig Jahren", in Kurtrierisches Jahrbuch, dl. 47, 2007 , p. 189-210.

(39) Benjamin ARNOLD, "Instruments of Power: the Profile and Profession of ministeriales within German Aristocratic Society, 1050-1225", in Thomas N. BISSON, ed., Cultures of Power: Lordship, Status, and Process in Twelfth-Century Europe, Philadelphia, University of Pennsylvania Press, 1995, p. 36-55 en K. Schulz, "Die Ministerialität", op. cit., p. 188. 
de Duitse Rijksstructuur dan de elite van Sint-Truiden ${ }^{(40)}$. Om die reden zal ik in het vervolg van dit artikel blijven spreken van de lokale elite, maar de term "ministerialen" vermijden. De leden van deze elite kwamen tijdens de eerste helft van de twaalfde eeuw herhaaldelijk, en zowel individueel als collectief, in conflict met de abten van Sint-Truiden. In de hierna volgende paragrafen gaan we dieper in op deze conflictstructuren.

\section{Confrontaties tussen de abdij en de lokale elite}

Conflicten tussen stedelijke elites en de abdij draaiden doorgaans om door de abdij betwiste toekenningen van een feodum of beneficium, op basis waarvan oppidani claimden recht te hebben op de daaruit resulterende opbrengsten van grond en belastingen ${ }^{(41)}$. De stedelingen zagen zich hierin dikwijls gesteund door andere machthebbers, zoals de heren van Duras, Limburg of Leuven. Dergelijke disputen sleepten vaak lang aan en vormden gedurende de hele volle middeleeuwen een probleem voor de abten ${ }^{(42)}$. Naast deze individuele verzuchtingen, dienden de abten ook het hoofd te bieden aan meer collectieve vormen van weerstand.

In $1119 \mathrm{kwam}$ het tot een dergelijk collectief conflict tussen de stadsbevolking en abt Rodulf (1108-1138). Dat jaar profileerden zich, in de context van de Investituurstrijd, twee pretendenten om bisschop Otbert (1091-1119) op te volgen. Tijdens dit zogeheten Luikse schisma steunde de kloostergemeenschap van Sint-Truiden Frederik van Namen, de pauselijke kandidaat en broer van graaf Godfried van Namen, die eveneens op graaf Walram van Limburg, Goswin heer van Valkenburg, de andere abten uit het diocees, het grootste deel van de Luikse clerus, de inwoners van de Luikse civitas en de stedelijke elite van Hoei kon rekenen. De Truiense stadsgemeenschap daarentegen koos onder aanvoering van de graaf van Duras de zijde van Frederiks opponent, aartsdiaken Alexander van Gulik, die ook gesteund werd door onder meer graaf Godfried van Leuven, de voogd van Haspengouw Reinier, graaf Lambert van Montaigu en de militairen uit de familia van het kapittel van Saint-Lambert te Luik ${ }^{(43)}$. De eerste continuator zet in de Gesta abbatum Trudonensium

(40) In zijn brief aan de bisschop van Metz vermeldt Rodulf twee ministerialen: één van de bisschop van Luik en één van die van Metz: Rodulfus TRUdONEnsis, Gesta abbatum Trudonensium, ed. cit., p. 26-27. De eerste continuator heeft het over een zekere kastelein en ministeriaal van de keizer: GISLEBERTUS TRUDONENSIS, Gesta abbatum Trudonensium, continuatio prima, ed. cit., p. 58. Tijdens het begin van de $13^{\text {de }}$ eeuw duiken er wel ministeriales op in de oorkonden van Sint-Truiden. Meer informatie over deze groep vindt men in E. LINCK, Sozialer Wandel, op. cit., p. 124-138.

(41) Bijvoorbeeld: Rodulfus TRUdonensis, Gesta abbatum Trudonensium, ed. cit., p. 49-50, 56 en 63; GISLEBERTUS TRUDONENSIS, Gesta abbatum Trudonensium, continuatio prima, ed. cit., p. 20-29 en Ch. Ріот, Cartulaire de l'abbaye, op. cit., dl. 1, nr. 49, p. 65-66. Zie ook E. LincK, Sozialer Wandel, op. cit., p. 121.

(42) Een oorkonde uit 1249 van de aartsbissschop van Keulen toont aan dat de abten van Sint-Truiden meer dan een eeuw later nog met soortgelijke problemen geconfronteerd werden: Ch. Piot, Cartulaire de l'abbaye, op. cit., dl. 1, nr. 210, p. 246-247.

(43) Jean-Louis KUPPER, "La double mort de l'évêque de Liège Frédéric de Namur $(\uparrow 1121)$ ", in Natalie FRYDE \& Dirk REITZ, eds., Bischofsmord im Mittelalter, Göttingen, 2003, p. 160-162; Jean-Louis KUPPER Liège et l'Église impériale (XI ${ }^{e}-X I I^{e}$ siècles), Luik, 
uitvoerig uiteen hoe de bisschopsstrijd grote verdeeldheid zaaide. Door zijn trouw aan de pauselijke kandidaat kwam de abt in een penibele situatie terecht. Onder de leiding van de graaf van Duras vochten de Truienaars mee in een militaire campagne te Hoei tegen Frederik van Namen ${ }^{(44)}$. Bovendien bood de stadsgemeenschap de tegenkandidaat Alexander meermaals onderdak aan wanneer hij uit Luik was verdreven ${ }^{(45)}$. Waarom de stedelingen niet de zijde kozen van Frederik van Namen, die uiteindelijk aan het langste eind trok, en bijgevolg tegen de wil van de abt ingingen, is onduidelijk. Klaarblijkelijk primeerde in dit conflict hun band met de ondervoogd, de graaf van Duras, op de relatie met hun heer, de abt. Voor abt Rodulf betekende deze keuze voor de keizerlijke partij onmiskenbaar de excommunicatie van de partijgangers van Alexander. De hertog van Leuven en de Truiense ondervoogd, de graaf van Duras, die zich aangevallen voelden door de excommunicatie, reageerden door goederen van de abdij in bezit te nemen. De gespannen verhouding tussen de abt en de stedelingen werd in 1120-1121 ten top gedreven, wanneer de abt weigerde om de uitvaartplechtigheid van een zieke dame uit de stedelijke elite te verzorgen, indien er mannen aanwezig waren die aan de zijde van Alexander hadden gestreden. De familie van de zieke vrouw ontketende vervolgens een opstand (seditio) onder de stadsbevolking en kreeg hierbij opnieuw de steun van de ondervoogd ${ }^{(46)}$. Met de goedkeuring van de graaf van Leuven verzamelde deze laatste op paasmaandag onder klokgelui de stedelingen op het plein voor de abdij. Het volk uitte allerlei klachten en frustraties en eiste het aftreden van de $a b t^{(47)}$. De dag nadien trachtte de graaf van Loon beide partijen tot een consensus te brengen, maar dit was vergeefse moeite. Rodulf zag zich gedwongen Sint-Truiden te verlaten. Hij bracht meer dan twee jaar in ballingschap door in de abdijen van achtereenvolgens Gent, Keulen, Kornelimünster en Deutz om ten slotte abt te worden van het klooster van SintPantaleon te Keulen. Pas in 1123, nadat bisschop Frederik in 1121 al onder zeer verdachte omstandigheden was overleden, kon hij terugkeren naar Sint-

Droz, 1981, p. 146-154 en Kevin SCHMIDT, "Alexandre ${ }^{\text {er }}$ de Liège et Raoul de Saint-Trond: une alliance de circonstance?", in Belgisch Tijdschrift voor Filologie en Geschiedenis, dl. 93, 2015, 3-4, p. 655-657.

(44) Gislebertus Trudonensis, Gesta abbatum Trudonensium, continuatio prima, ed. cit., p. 59-60.

(45) Gislebertus Trudonensis, Gesta abbatum Trudonensium, continuatio prima, ed. cit., p. 57: Alexander ciuitate et castellis eiectus, sub predictis tutoribus nostro oppido frequenter se recipiebat, et tantorum malorum incendium acriter se agebat. Oppidani nostri omnes illi fauorales erant, utpote semper leuissimus ad talia populus. Zie ook Claude GAIER, Art et organisations militaires dans la principauté de Liège et dans le comté de Looz au Moyen Âge, Brussel, Koninklijke Academie van België, 1968, p. 234-237.

(46) Gislebertus Trudonensis, Gesta abbatum Trudonensium, continuatio prima, ed. cit., p. 59.

(47) Gislebertus Trudonensis, Gesta abbatum Trudonensium, continuatio prima, ed. cit., p. 60: Advocatus [...] nunc vero magis in iram et furorem propter supradictam exprobrationem contra eum succensus [...] secundo die pasche in atrium ęcclesię veniens, pulsata campana populum conuocat. Vbi de illo pariter ceperunt tumultuari et conqueri et uicissim fauere eius derogatione. Mandatus ad eos exire, recusat. Aduocatus homines eius pro precepto suo nolentes eum exfestucare, exfestucat. Die illa tota satis turbe actum est in turba. Zie ook J.-L. CHARLES, La ville, op. cit., p. 357. 
Truiden ${ }^{(48)}$. Daar moet hij de opdracht hebben gegeven tot het redigeren van een Vita metrica Friderici episcopi Leodiensis, maar moest hij tegelijk een aantal jaren later wel nog meemaken dat Alexander alsnog tot bisschop werd gewijd (1128-1135) ${ }^{(49)}$. Wat voor ons echter vooral van belang is, is dat in dit conflict een externe factor - met name de bisschopsstrijd - de stadsbevolking van Sint-Truiden gedwongen had te kiezen tussen de abt en de ondervoogd, de graaf van Duras. Ook tijdens de partijvorming gedurende de decennialange abtsstrijd die het abbatiaat van Rudolf voorafging (1082-1108), schipperden groepen van stedelingen tussen enerzijds hun trouw aan de ondervoogd en anderzijds die aan verschillende pretendenten die door de monastieke gemeenschap naar voor werden geschoven ${ }^{(50)}$.

Tijdens het abbatiaat van Folkard (1138-1145) nam de stedelijke elite een tweede keer het voortouw in een opstand. Ditmaal was de inzet van het conflict het recht van de abt om taksen te heffen op het brouwen van bier. Deze brouwbelastingen waren een doorn in het oog van de rijke stedelingen, die de meeste brouwerijen in hun bezit hadden. De taksen gingen vermoedelijk terug op het recht op het maken en verhandelen van gruit, het kruidenmengsel dat bier van smaak voorzag en de houdbaarheid verlengde ${ }^{(51)}$. Zowel uit de continuaties van de Gesta als uit verschillende oorkonden blijkt dat deze belastingen met de regelmaat van de klok de aanzet tot disputen gaven. In 1136 had abt Rodulf reeds zijn beklag gedaan in een brief aan de bisschop van Metz omdat hij herhaaldelijk had moeten ingrijpen, nadat verschillende stedelingen beweerd hadden het gruitrecht in leen of pand te hebben ${ }^{(52)}$. In 1140 bevestigde de bisschop van Metz op vraag van de nieuwe abt Folkard, en met de bekrachtiging van de bisschop van Luik, de abbatiale rechten op de bierheffingen ${ }^{(53)}$. Ondanks deze regeling barstte luttele jaren later, in 1143-1144, in alle hevigheid een nieuw conflict los ${ }^{(54)}$. De Truiense elite (primates en potentiores) ver-

(48) Gislebertus TRudonensis, Gesta abbatum Trudonensium, continuatio prima, ed. cit., p. 60-68. Zie ook Gustave BoEs, L'abbaye de Saint-Trond. Des origines jusqu'à 1155, Tongeren, Michiels, 1970, p. 212-216 en S. HAARLÄNDER, "Kloster und Stadt", op. cit., p. 181-182.

(49) Godefroid KURTH, "Vita metrica sancti Friderici episcopi Leodiensis ex cod. Londiniensi (Addit. Mss. 24914) nunc primum edita", in Analecta Bollandiana, dl. 2, 1883, p. 259-270. Voor verdere informatie over deze episode en de relatie tussen Rodulf en Alexander, zie K. SCHMIDT, "Alexandre", op. cit., p. 647-667.

(50) Over dit conflict: R. KüNZEL, Beelden en zelfbeelden, op. cit., p. 156-162.

(51) Joseph DECKERS, "Recherches sur l'histoire des brasseries dans la région mosane au Moyen Âge", in Le Moyen Age, dl. 76, 1970, p. 445-491 en Co VAN DE KIEFT, "Gruit en ban", in Tijdschrift voor Geschiedenis, d1. 77, 1964, p. 158-168.

(52) Gislebertus TRUdONEnsis, Gesta abbatum Trudonensium, continuatio prima, ed. cit., p. 31: Ius omne bracenarum, quod propter grutam soluitur in ceruisia, fratrum est, sicut testatur cartha quam habemus de illa iusticia. [...] Hoc plures oppidanorum nostrorum ita inuaserant, partim dicentes suum esse feodum, partim se habere in uadio, ut paruissimi inde reditus ad fratres uenirent. Longa inter me et illos fuit decertatio. Que ex parte etiam usque hodie manet.

(53) Gesta abbatum Trudonensium, continuatio secunda, ed. cit., dl. 2, p. 13 en 16 en Ch. PIot, Cartulaire de l'abbaye, op. cit., dl. 1, nr. 43, p. 56-58.

(54) Gesta abbatum Trudonensium, continuatio secunda, ed. cit., dl. 2, p. 21: Primates namque ville nostre omnes fere potentiores jur cambarum in villa nostra constructarum ecclesie juri subjacere, putantes, si in hac violentia contra abbatem prevaluissent, eas perpetuo liberas se posse retinere. 
enigde zich volgens de tweede continuator van de Gesta in een samenzwering (conspiratio) en kwam opnieuw in opstand tegen de heffingen. De abt beriep zich vanzelfsprekend op de autoriteit van de bisschop van Metz om het pleit te winnen en steunde daarbij op de oorkonden waarin de bisschoppen het gruitrecht erkenden. Dit kon de opstandelingen evenwel niet op andere gedachten brengen, waardoor de abt zich genoodzaakt zag een brief te schrijven naar de bisschop. In diens antwoord maande de bisschop de stedelingen tevergeefs aan om gehoor te geven aan de eisen van de abt. Uiteindelijk excommuniceerde de abt de opstandelingen. Vervolgens zochten de Truiense brouwers en hun medestanders zoals eerder in de geschiedenis hulp bij de graaf van Duras. Beide partijen bepleitten hun zaak voor de bisschop van Luik, die de excommunicatie van de stedelingen evenwel bevestigde ${ }^{(55)}$. De reacties van de stedelingen waren verdeeld, sommigen onderwierpen zich aan de macht van de abt, anderen bleven hardnekkig weigeren de belasting te betalen ${ }^{(56)}$. Hoewel de opstand hiermee was afgelopen, zou de discussie over de brouwbelastingen nog op z'n minst twee eeuwen aanslepen. In de veertiende-eeuwse voortzetting van de Gesta valt te lezen dat, wanneer de bisschop van Luik in 1314 de toestemming verleende om een commune op te richten, de communale leiders een nieuwe een poging deden om de brouwbelastingen af te schaffen ${ }^{(57)}$.

Ondanks het feit dat de narratieven over de "rebelse" daden van de Truiense oppidani zonder meer gekleurd zijn door het partijdige standpunt van hun monastieke auteurs, geven ze ons heel wat informatie over de wijze waarop de stedelijke elite en de abdij conflicten voerden. Een eerste opvallende vaststelling hierbij is dat de rol van de monniken in deze conflicten door de auteurs van de Gesta wordt doodgezwegen. Het blijft ook onduidelijk in welke mate zij als gemeenschap echt betrokken partij waren en of zij zich als één man achter de abt schaarden. In de beschrijvingen komt immers voornamelijk een dispuut tussen abt enerzijds en stedelingen anderzijds naar voor. Naast deze twee rivaliserende partijen tekenen zich in de teksten duidelijk medestanders en arbiters af. De graven van Duras maakten herhaaldelijk gebruik van de bestaande spanningen tussen de abten en de stedelingen om de relatie tussen deze twee te verzwakken. In deze specifieke conflicten toonden de graven van Duras zich vooral trouwe bondgenoten van de stedelijke elites ${ }^{(58)}$, terwijl de abten zich vaak beriepen op de hulp van de bisschoppen. Als arbiter traden zowel de graaf van Limburg als de Luikse bisschop op. Voorts ontplooiden de verschillende partijen elk hun eigen specifieke conflictstrategieën. De abten konden beroep doen op de hogere autoriteit van de bisschoppen, overgaan tot excommunicatie

(55) Gesta abbatum Trudonensium, continuatio secunda, ed. cit., dl. 2, p. 21-24.

(56) Ibid., p. 23: Fuerunt preterea quamplures alii ejusdem contra abbatem conspirationis rei, qui satisfacientes ecclesie, ut prediximus, ab excommunicatione meruerunt absolvi. Alii autem obstinatie sue timore inflati, nec resipiscere volentes, exommunicati defuncti sunt.

(57) Gesta abbatum Trudonensium, continuatio tertia, ed. cit., dl. 2, p. 248-250 en Joseph DECKERS, "Gruit et droit de gruit. Aspects techniques et fiscaux de la fabrication de la bière dans la région mosane au Moyen Âge", in Handelingen van het XLI Congres te Mechelen 3-6-IX-1970, Mechelen, 1971, dl. 2, p. 189-190.

(58) Zoals ik verder zal bespreken waren de graven van Duras in andere conflicten dan weer tegenstanders van coalities tussen de stadsbevolking en de abdij. 
van de stedelingen en weigeren de sacramenten toe te dienen ${ }^{(59)}$. De stedelijke elite van haar kant negeerde het gezag en de eisen van de abt of weigerde belastingen te betalen. Net als de abt konden de stedelingen in een latere fase van het conflict beroep doen op een hogere autoriteit, de ondervoogd. Zoals we zagen, kon de stadsgemeenschap met behulp van de lokale machthebbers zelfs de abt uit het klooster en de stad verdrijven. Dit gebeurde na mobilisatie onder klokgelui, hetgeen een bekende praktijk was in stadsgemeenschappen tijdens de volle en late middeleeuwen ${ }^{(60)}$. Ook een dergelijke weigering van de stedelijke gemeenschap om de stadsheer - wat de abt in 1120 ook effectief voor de Truienaars was - in de stad te laten verblijven, was een vaak voorkomende verzetsdaad. Zo dwong de commune van Kamerijk bijvoorbeeld in de volle middeleeuwen herhaaldelijk haar bisschoppen de stad te verlaten op momenten van conflict ${ }^{(61)}$.

De conflictmechanismen in de machtsstrijd tussen de stedelingen en de abten in Sint-Truiden, en de betrokkenheid van voorstanders, tegenstanders, medestanders en arbiters, vertonen bovendien grote gelijkenissen met de resultaten van het onderzoek van Patrick Geary naar de conflictenmechanismen tussen lokale aristocraten en kloosterinstellingen in casestudies over de Provence ${ }^{(62)}$. De Truiense opstanden blijken deel uit te maken van wat Geary conflictual structures noemt: de onderlinge machtsverhoudingen tussen de verschillende actoren worden continu heronderhandeld, wat met de regelmaat van de klok tot openlijke conflicten leidt. Wat in analyses zoals die van Geary echter minder aan bod komt, zijn soms pure economische belangen die als primaire beweegreden aan de grondslag konden liggen van het handelen van tegengestelde partijen, zeker in een stedelijke context. Het Truiense oproer rond het gruitrecht, vormt daarvan een belangrijke indicatie. Ook elders in het Luikse blijken bierbelastingen een belangrijk discussiepunt tussen stadsheren en stadsbevolking. In 1068, twee jaar nadat de burgenses van Hoei

(59) Excommunicatie en het weigeren van het verzorgen van de sacramenten zijn ook de twee voornaamste conflictstrategieën van de kloostergemeenschappen volgens $P$. GEARY, "Living with Conflicts", op. cit., p. 47-49. Over het gebruik van excommunicatie in het begin van de twaalfde eeuw in het bisdom Luik, zie Ortwin HuYSMANS, "Excommunication under Discussion in the Early Twelfth Century Diocese of Liège. A Comparative Inquiry into the Opinions of Lambert of St.-Hubert and Sigebert of Gembloux", in Trajecta. Tijdschrift voor de Geschiedenis van het Katholiek Leven in de Nederlanden, dl. 23, 2004, 1, p. 37-64.

(60) Jelle HaEmers, "A Moody Community? Emotion and Ritual in Late Medieval Urban Revolts", in Élodie LECUPPRE-DESJARDIN \& Anne-Laure VAN BRUANE, eds., Emotions in the Heart of the City (14 $4^{\text {th }}-16^{\text {th }}$ Century), Turnhout, Brepols, 2005, p. 71-73; Alain SAINT-DENIS, "L'apparition d'une identité urbaine dans les villes de commune de France du Nord aux XII ${ }^{\mathrm{e}}$ et XIII ${ }^{\mathrm{e}}$ siècles", in Marc BoONE \& Peter STABEL, eds., Shaping Urban Identity in Late Medieval Europe, Leuven, Garant, 2000, p. 71-73 en Peter STABEL, "The Market-Place and Civic Identity in Late Medieval Flanders", in M. BoONE \& P. STABEL, eds., Shaping Urban Identity, op. cit., p. 53.

(61) Gesta episcoporum Cameracensium, ed. Ludwig Conrad Bethmann, Hannover, Hahn, 1846 (Monumenta Germaniae Historica, Scriptores, 7), p. 431 en Gesta Gerardi II, ed. L.C. Bethmann, Hannover, Hahn, 1846 (Monumenta Germaniae Historica, Scriptores, 7), p. 498. Zie ook R. KüNZEL, Beelden en zelfbeelden, op. cit., p. 190-199 en Henri Dubrulle, Cambrai à la fin du Moyen Âge, Lille, Imprimerie Lefebvre-Ducrocq, 1904 , p. 29-30 en 42-43.

(62) P. GEARY, "Living with Conflicts", op. cit., p. 136-160. 
geprivilegieerd werden met allerlei voorrechten, zag de bisschop van Luik zich genoodzaakt afstand te doen van zijn monopolie op het gruit in Hoei, terwijl hij daarentegen wel belastingen kon blijven innen op het brouwen van bier ${ }^{(63)}$.

In tegenstelling tot veel andere conflicten in verstedelijkte centra in deze periode, in het bijzonder in Noord-Frankrijk en Vlaanderen, was de inzet voor de stedelingen van Sint-Truiden dus niet meteen het politieke en juridische bestuur van de stad. De Truiense elites wisten zich te verenigen, maar deden dit niet vanuit een streven naar communale autonomie. Het waren aanvankelijk vooral de machtsrelaties met de lokale aristocratie en economische belangen die de episoden van opstandigheid in het verstedelijkingsproces tekenden.

\section{Verzoening en amicitia}

Opstanden en betwiste usurpaties vormen slechts één aspect van de relaties tussen de abten en de leidende stedelijke groepen. Beide partijen hadden over het algemeen meer baat bij vriendschappelijke relaties. Wederzijdse schenkingen, gestoeld op het principe van do ut des, waren een belangrijke manier om vriendschapsbanden te creëren en onderhouden ${ }^{(64)}$. Vanaf het begin van de twaalfde eeuw treffen we in de bronnen ook leden van de stedelijke elite van Sint-Truiden aan die participeerden in de giftcultuur ten aanzien van de abdij. Zo vinden we onder de weldoeners van het klooster tijdens deze periode een villicus, een gruiter, schouten van zowel de bisschop van Metz als van de abt, de nazaten van een seneschalk en verschillende andere personen die opdoken als getuigen in de oorkonden ${ }^{(65)}$.

De vroegste schenkingen van stedelingen waarover we via de Gesta geïnformeerd zijn, kwamen er in de eerste decennia van de twaalfde eeuw op vraag van abt Diederik, Rudolfs voorganger, ter herstelling van het klooster ${ }^{(66)}$. Vanaf 1138 vinden we bovendien geoorkonde pro anima-giften van stedelingen terug. De spirituele compensaties van de abdij voor de materiële giften gaven uitdrukking aan de harmonieuze eenheid tussen de gegoede stedelingen en de monniken. Naast bevordering van het zielenheil en memoria ter nagedachtenis van de overledenen, ontvingen de leken als tegengift van de abdij dikwijls een begraafplaats in of nabij het klooster, de mogelijkheid om op latere leeftijd lekenbroeder te worden en soms een prebende vergelijkbaar met hetgeen de monniken toekwam ${ }^{(67)}$. Zowel ruimtelijk, religieus als ideologisch bracht de

(63) S. Bormans \& M.L. Polain, Recueil des ordonnances, op. cit., dl. 1, p. 7, nr. 8.

(64) Arnoud-Jan A. Bissterveld, Do ut des. Gift Giving, Memoria and Conflict Management in the Medieval Low Countries, Hilversum, Verloren, 2007, p. 38-39.

(65) Gislebertus TRUdonensis, Gesta abbatum Trudonensium, continuatio prima, ed. cit., p. 29-31, 48 en 81-82; Gesta abbatum Trudonensium, continuatio secunda, ed. cit., dl. 2, p. 20-25 en 37 en Ch. PIOT, Cartulaire de l'abbaye, op. cit., dl. 1, nr. 40, p. 53-54 en nr. 49, p. 65-66.

(66) Rodulfus TRudonensis, Gesta abbatum Trudonensium, ed. cit., p. 62: Qui dum facundi oris gratia contionaretur diebus pasce siue pentecosten in ecclesia beatę Marie ad populum, frequenter eis eliciebat decem aut duodecim, plus ue minus ue marcarum ad monasterii reparandi auxilium.

(67) Gesta abbatum Trudonensium, continuatio secunda, ed. cit., d1. 2, p. 17-19; Ch. Pıот, Cartulaire de l'abbaye, op. cit., dl. 1, nr. 45, p. 59-60, nr. 49, p. 65-66 en nr. 50, p. 66-68. Zie ook A.-J. Bijsterveld, Do ut des, op. cit., p. 118-120. 
giftrelatie de toenadering tussen de stedelijke elite en de abdij tot uitdrukking. Door middel van giften ontstonden er relaties van gebedsverbroedering (societas fraternitatis) tussen de abdij en de leken die toegang verwierven tot de gebedsgemeenschap en de goede werken van de abdij. De gulle schenkers van Sint-Truiden werden hoogstwaarschijnlijk opgenomen in de Sint-Euchariusbroederschap, die reeds in het midden van de elfde eeuw zou zijn gesticht en waarvan de statuten ons zijn overgeleverd in twee oorkonden uit $1192^{(68)}$. Daarnaast bestond er in de twaalfde eeuw in Sint-Truiden op zijn minst één ander broederschap op parochiaal niveau: de Onze-LieveVrouwbroederschap, in de volkstaal gulde genoemd. Deze broederschap was verbonden aan de gelijknamige parochiekerk, die tussen 1055-1082 opgericht werd door abt Adelard II op het grondgebied van de abdij ${ }^{69)}$. De Onze-LieveVrouwbroederschap, waarover de vroegste bronnen uit 1171 dateren, had een sterke band met de abdij. De abt had het patronaat over de broederschap in zijn bezit en ontving er elk jaar twee schellingen van ${ }^{(70)}$.

De giftcultuur kon tevens aangewend worden om conflicten op te lossen tussen de stedelijke bevolking en de kloostergemeenschap en terzelfdertijd de wederzijdse relaties te versterken. Zowel de weduwe van seneschalk Hezelo, die volgens de monniken onrechtmatig aanspraak maakte op bezittingen van de abdij, als Ruthard Gym, die één van diegenen was die de brouwbelastingen contesteerden, legden hun geschillen omstreeks 1144 met abt Folkard bij door middel van een schenking ${ }^{(71)}$. Ook Adam, de schout van de bisschop van Metz, kwam na de gruitopstand tot een overeenkomst met de abt. Adams vader Arnulf, voormalig schout, was op het ogenblik van het conflict overigens lekenbroeder in het klooster van Sint-Truiden, wat blijk geeft van de grote verbondenheid tussen deze familie en de abdij ${ }^{(72)}$. In tegenstelling tot Ruthard deed Adam geen schenking van één van zijn eigendommen, maar moest hij enkel zijn verplichtingen ten opzichte van de abdij erkennen en de achtergehouden bierbelastingen betalen. In ruil mocht hij manschap doen aan de abt en ontving hij allerlei schenkingen. Hiermee werd niet alleen het geschil tot een goed einde gebracht, maar werden ook de sociale posities van beide partijen in de verf gezet. Naast de materiële schenkingen genoot Adam immers van het aanzien gekoppeld aan het "man zijn" van de abt, terwijl de hiërarchische positie van de abt als stadsheer en overste van Adam bevestigd werd.

De grote verschillen in de toegevingen na het conflict over de brouwbelastingen zijn opmerkelijk. Waar Ruthard een stuk grond moest schenken om tot een vergelijk te komen, volstond het voor Adam om de achterstallige taksen te

(68) Ch. Ріот, Cartulaire de l'abbaye, op. cit., dl. 1, nr. 111, p. 151-152 en nr. 113, p. 154-155. Zie ook Arnoud-Jan A. BIJSTERVELD \& Paul TRIO, "Van gebedsverbroedering naar broederschap. De evolutie van het fraternitas-begrip in de Zuidelijke Nederlanden in de volle Middeleeuwen (I)", in Jaarboek voor Middeleeuwse Geschiedenis, dl. 6, 2003, p. $18-21$.

(69) J.-L. Charles, La ville, op. cit., p. 194-196.

(70) Ch. Ріот, Cartulaire de l'abbaye, op. cit., dl. 1, nr. 88, p. 116-117. Zie ook A.J. BIJSTERVELD \& P. TRIO, "Van gebedsverbroedering naar broederschap (I)", op. cit., p. 34-35.

(71) Ch. Ріот, Cartulaire de l'abbaye, op. cit., dl. 1, nr. 49, p. 65-66 en Gesta abbatum Trudonensium, continuatio secunda, ed. cit., dl. 2, p. 22-23

(72) Gesta abbatum Trudonensium, continuatio secunda, ed. cit., dl. 2, p. 24. 
betalen. Daarenboven kreeg hij een feodum van de abt. Dergelijke verschillen waren uiteraard terug te voeren op de positie die men bekleedde in het lokale maatschappelijke netwerk. De abten waren er blijkens de bronnen bij gebaat om de dienaren van de bisschoppen van Metz, zoals schout Adam, te vriend te houden. Zo schreef Rodulf over één van de voorgangers van Adam dat die hem slechts de helft diende te restitueren van wat hij zich onrechtmatig had toegeëigend, "omdat ik [Rodulf] het nuttig heb geacht voor de kerk indien de villicus van de bisschop een benificium van de abt had"(73). Een zelfde gedachtegang tekent het fragment in de Gesta waarin over schout Adam wordt gehandeld:

“Daarom beschouwde de abt de vriendschap met zo'n man noodzakelijk; hij gaf hem op aanraden van zijn vrienden tien schellingen in beneficium, opdat hij hem tot zijn man zou maken, aangezien hij zijn man niet was en hij in plaats van trouw meer trouw en in plaats van vriendschap meer vriendschap zou teruggeven" ${ }^{(74)}$.

Deze laatste zinsnede moet de tweede continuator van de Gesta overigens uit een oorkonde uit 1146 hebben gehaald. In die oorkonde kent bisschop Hendrik II van Luik (1145-1164) de burgenses van Sint-Truiden dezelfde rechten toe als de Luikenaars met betrekking tot de synodale en kerkelijke rechtspraak. De Truienaars moesten daartoe met een eed hun trouw en vriendschap ten opzichte van de bisschop bevestigen, opdat ze "van vrienden grotere vrienden en van trouw meer trouw zouden maken" (75). In geen enkel ander diplomatisch stuk uit de Lage Landen vindt men deze formulering terug ${ }^{(76)}$.

Schenkingen reguleerden dus de sociale en politieke verhoudingen en droegen bij tot de creatie van van fidelitas, amicitia en servitium tussen de verschillende Truiense actoren. Het beëindigen van de conflicten met de abdij was in vele gevallen een hoogst individuele aangelegenheid, waarbij men op basis van zijn of haar positie in de lokale machtsstructuur tot een overeenkomst diende te komen. Dit persoonlijke karakter van de conflictoplossing strookt met de analyse van de conflicten tussen stadsgemeenschap en abdij. De relaties van de gegoede stedelingen met de abdij werden immers vooral bepaald door de particuliere belangen van de stedelijke elite. De acties van deze elite werden, zoals we al zagen, niet gedreven door een communaal ideaal over hoe de stad te besturen.

(73) Eigen vertaling, Rodulfus TRUdonensis, Gesta abbatum Trudonensium, ed. cit., p. 27: quoniam utile vidi esse aecclesiae, ut villicus episcopi beneficiatus esset abbatis.

(74) Eigen vertaling van Gesta abbatum Trudonensium, continuatio secunda, ed. cit., d1. 2, p. 24: Considerans itaque abbas necessariam talis viri amicitiam, quia homo eius non erat, ut hominem suum eum faceret, et de fidele fidelior et de amico amicitior redderetur, consilio amicorum suorum ei decem solidos in benefitium dedit.

(75) S. Bormans \& M.L. Polain, Recueil des ordonnances, op. cit., dl. 1, p. 17-18: de amicis amicitiores et de fidelibus fideliores efficiantur. In deze oorkonde duikt Adam overigens zelf op als getuige en lid van de familia van Sint-Truiden.

(76) Deze formulering vindt men in elk geval niet terug in de Diplomata Belgica, een databank van de uitgegeven oorkonden tot ongeveer 1250. Thérèse DE HEMPTINNE, Jeroen DePloige, Jean-Louis KupPer \& Walter PREVEnIER, eds., Diplomata Belgica. Les sources diplomatiques des Pays-Bas méridionaux au Moyen Age. The Diplomatic Sources from the Medieval Southern Low Countries, in www.diplomata-belgica.be (2015), Brussel, Koninklijke Commissie voor Geschiedenis, 15 december 2015. 
De verhoudingen tussen de stedelingen en de abdij werden niet alleen veruitwendigd in giftrelaties, maar ook via andere rituelen; niet in het minst de rituelen die gepaard gingen met het aantreden en de aanstelling van nieuwe abten. Abten moesten bij hun aantreden geloften afleggen in de abdijkerk van Sint-Truiden. Dit was althans zo in de veertiende eeuw, toen de abten ten overstaan van de schepenen en stadsbewoners trouw beloofden ${ }^{(77)}$. In de elfde en twaalfde eeuw bestond reeds de gewoonte dat de stedelingen en de beneficiati op de dag van aantreden trouw aan de abt zwoeren (fidelitatem facere) en manschap deden (hominium facere) ${ }^{(78)}$. Toch konden dergelijke beloften ook problematisch worden. Dit blijkt onder meer uit de argumenten die de partij van Rodulf in 1108 aan de afgevaardigden van de bisschop van Metz voorlegden om aan te tonen dat hun tegenstander, Herman II, geen canonieke aanstelling had ontvangen. Men beschuldigde Herman II ervan de mannen van de kerk van Sint-Truiden (homines ęcclesię nostrę) aan zich te hebben gebonden door eed en manschap, hoewel hij niet als abt was aangesteld en dus onrechtmatig deze eden ontving ${ }^{(79)}$. Anderzijds moesten de abten zich ervoor hoeden geen trouw te ontvangen van personen die onrechtmatig bezittingen van de abdij claimden. Wanneer men op de eerste dag van Rodulfs abbatiaat trouw aflegde, liet de abt zich bijstaan door de proost, de keldermeester en enkele ouderen "opdat hij geen belofte van trouw zou aanvaarden van iemand die de broeders beschuldigden iets van hun prebende onrechtvaardig achter te houden"(80).

Behalve van deze eden, maken de eerste en de tweede voortzetter van de Gesta abbatum Trudonensium ook melding van luisterrijke processies waarmee de nieuwe abten werden ontvangen. Deze processies weerspiegelden de eenheid en de goede relatie tussen abt en gemeenschap. Zo'n ontvangst kon ook een verzoenend doel voor ogen hebben ${ }^{(81)}$. Zo werd abt Rodulf, nadat hij door de stedelingen voor twee jaar uit de stad verbannen was, met een feestelijke processie verwelkomd, "zodat de luister van dit onthaal de smaad van het heengaan overtrof"(82). De auteur van de Gesta zag de ontvangst

(77) Een uitvoerige beschrijving van dit intrederitueel is overgeleverd in een veertiende eeuwse voorzetting van de Gesta: Gesta abbatum Trudonensium, continuatio tertia, ed. cit., dl. 2, p. 305-306.

(78) Rodulfus Trudonensis, Gesta abbatum Trudonensium, ed. cit., p. 31 en 81 en Gislebertus TRUdonensis, Gesta abbatum Trudonensium, continuatio prima, ed. cit., p. 18. Het was vermoedelijk eenzelfde band van manschap en trouw die de bovengenoemde iudex Adam en abt Folkard met elkaar aangingen om hun vriendschaps- en vertrouwensrelatie te herstellen na het conflict.

(79) Rodulfus TRUdOnEnsis, Gesta abbatum Trudonensium, ed. cit., p. 90.

(80) Gislebertus TRUdONENSIS, Gesta abbatum Trudonensium, continuatio prima, vert. E. LAVIGNe \& Wiebe AlBerTs, Kroniek van de abdij van Sint-Truiden, dl 1: 6281138, Assen-Maastricht, Van Gorcum, 1986 (Maaslandse monografieën, 43), p. 103 en ed. cit., p. 18: ut nullius manus neque fidelitatem reciperet, quem fratres de prebenda sua iniuste aliquid tenere querentur.

(81) Ook in de late middeleeuwen werden stedelijke opstanden gecompenseerd door middel van luisterrijke intredes van de heer: J. HAEMERS, "A Moody Community?", $o p$. cit., p. 79.

(82) Gislebertus TRUdonensis, Gesta abbatum Trudonensium, continuatio prima, vert. E. LAVIGNe \& W. AlBeRTS, Kroniek van de abdij I, op. cit., p. 151 en ed. cit., p. 68: et maiori gloria [...] suscepto quam contumelia exiuisset. 
met andere woorden als compensatie voor het aangedane leed. Dit aantreden gebeurde niet toevallig enkele dagen na Pinksteren. Tijdens deze dagen vonden de bankruisprocessies plaats. Bij deze gelegenheid kwamen de bevolkingen van de naburige parochies in processie naar hun kerkelijke centrum, de abdij van Sint-Truiden, en deden ze daar een jaarlijkse schenking ${ }^{(83)}$. Dergelijke publieke aangelegenheden, waarbij veel volk te been was, vormden ideale gelegenheden voor abtsintredes. Ook Rodulfs opvolger, abt Folkard, trad in te Sint-Truiden tijdens de dagen na Pinksteren ${ }^{(84)}$.

Ook enkele weken voor de bankruisprocessies, ten tijde van de kruisdagen, vond in de omgeving van Sint-Truiden jaarlijks een andere, gelijkaardige processie plaats. Tijdens die kruisdagen brachten de monniken en een deel van de stedelijke elite namelijk in processie zelf een bezoek aan de omliggende dorpen ${ }^{(85)}$. Beide processies benadrukten dus de eenheid tussen de abdij en haar omgeving en tussen de monniken en de lekenbevolking. Tegelijkertijd werd ook de centrumfunctie van de abdij van Sint-Truiden in de verf gezet ${ }^{(86)}$.

In 1085 maakte de keizersgezinde intrigant Luipo overigens al dankbaar gebruik van de kruisdagen om het abbatiaat te claimen ten nadele van Lanzo, de kandidaat die officieel door de bisschoppen van Metz en Luik als abt naar voren was geschoven. Nadat de stedelingen en de beneficiati trouw hadden beloofd aan Luipo, leidde deze laatste diezelfde dag de processies van de kruisdagen, vergezeld door een grote groep monniken en leken, terwijl zijn concurrent Lanzo zich gedwongen terugtrok in de abdij. De actie van Luipo, het volk en het merendeel van de broeders in de kruisprocessie en de trouwbetuiging, maakte dat uiteindelijk niet Lanzo, maar wel Luipo als daadwerkelijk hoofd van de gemeenschap werd erkend ${ }^{(87)}$. De kruisdagen vormen ook het onderwerp van een andere passage in de Gesta. In de eerste jaren van de twaalfde eeuw trad Rodulf - in zijn hoedanigheid van prior op tegen escalaties van deze processies, waarbij sommige monniken samen "met jonge lichtzinnige stedelingen"(88) de processies te paard aflegden voor de ogen van het volk. De Truiense elite en enkele monniken maakten dus van dergelijke manifestaties gebruik om hun sociale status tegenover de rest van de gemeenschap te etaleren. De abtsintredes en kerkelijke processies kenden met andere woorden dezelfde paradox: enerzijds weerspiegelden ze de eenheid van de gemeenschap, terwijl ze anderzijds de hiërarchische gelaagdheid van en

(83) Ursmer BERLIÈRE, "Les processions de croix banales", in Bulletin de la Classe des Lettres, dl. 8, 1922, p. 437; Jelle Lisson, "Grenzeloze macht? De territoriale politiek van de bisschoppen van Luik en Metz in de regio Zoutleeuw ( $8^{\text {ste }}-13^{\text {de }}$ eeuw)", in Trajecta. Tijdschrift voor de Geschiedenis van het Katholiek Leven in de Nederlanden / Religion, Culture and Society in the Low Countries, d1. 23, 2014, p. 12-15 en André VANRIE, "Les croix banales aux abbayes en Belgique au Moyen Âge", in Contributions à l'histoire économique et sociale, dl. 2, 1963, p. 7-27.

(84) Gesta abbatum Trudonensium, continuatio secunda, ed. cit., dl. 2, p. 11.

(85) U. Berlière, "Les processions", op. cit., p. 419-446 en Satoshi TADA, "The Creation of a Religious Centre: Christianisation in the Diocese of Liège in the Carolingian Period", in Journal of Ecclesiastical History, dl. 54, 2003, p. 222-227.

(86) S. TADA, "The Creation", op. cit., p. 223.

(87) Rodulfus Trudonensis, Gesta abbatum Trudonensium, ed. cit., p. 31.

(88) Gislebertus Trudonensis, Gesta abbatum Trudonensium, continuatio prima, vert. E. LAVIGNe \& W. AlBerTs, Kroniek van de abdij I, op. cit., p. 96 en ed. cit., p. 10-11: cum leuibus oppidanorum iunenibus. 
de breuklijnen binnen die gemeenschap blootlegden. Net zoals schenkingen, waren intredes en processies de ideale gelegenheden voor de elites van de stedelijke gemeenschap om hun sociale status te etaleren en hun verbondenheid met de abdij in de verf te zetten.

\section{Iurata pax: relaties met de regionale machthebbers}

De bevolking van Sint-Truiden raakte in de eerste helft van de twaalfde eeuw ook meermaals betrokken in conflicten met graven, hertogen en bisschoppen. Naast de ondervoogd, de graaf van Duras, trachtten vooral de graaf van Leuven en de bisschop van Luik invloed te verwerven in de stad. Met dit doel voor ogen sloten zowel de bisschop als de graaf regelmatig eedverbonden af met de stedelijke gemeenschap van Sint-Truiden.

De aanvang van een nieuwe bestuursperiode vormde vaak een cruciaal moment voor de verschillende actoren om hun posities binnen de geldende machtsstructuren weer in vraag te stellen. Dat bleek bijvoorbeeld bij het begin van het episcopaat van de Luikse prinsbisschop Alexander I van Gulik (1128-1135) die, zoals we hierboven al zagen, de voormalige tegenstander van de in 1121 wellicht vermoorde bisschop Frederik van Namen was. Als reactie op dreigementen van de heren van Duras en Leuven, nam bisschop Alexander in 1129 de stad Sint-Truiden in bescherming. De stedelingen en de bisschoppelijke partij zwoeren elkaar "wederzijdse trouw, raad en hulp"(89) en herstelden de stadsversterking ${ }^{(90)}$. Dit werd door de graven van Duras en Leuven, die Alexander in 1119 nog hadden gesteund, als een provocatie ervaren en zorgde ervoor dat het tot een open strijd tussen beide kampen kwam, waarbij de stad en het klooster van Sint-Truiden het strijdtoneel werden van een oorlog tussen de bisschop van Luik en de hertog van Limburg aan de ene zijde en de graven van Duras, Leuven en Vlaanderen aan de andere kant. In de slag bij Wilderen delfde deze laatste partij het onderspit. Uiteindelijk kwam het in 1131 tot een vredesovereenkomst tussen alle partijen ${ }^{(91)}$.

De Truiense stedelingen hadden niet alleen overeenkomsten met de bisschoppen van Luik, maar ook met de graven van Leuven. Dit blijkt uit het fragment in de Gesta over het vermaarde carnavaleske landschip, dat eerder al door Paul Bonenfant en Rudi Künzel is bestudeerd. In 1135 werd volgens deze passage een landschip door wevers van Kornelimünster naar Sint-Truiden getrokken. Het landschip werd met groot enthousiasme onthaald door de stadsbewoners, die de wevers kleineerden en gedurende meer dan

(89) Gislebertus TRUdonensis, Gesta abbatum Trudonensium, continuatio prima, ed. cit., p. 74: invicem fidem, consilium et auxilium.

(90) Ibid., p. 74.

(91) Ibid., p. 74-75. Over de slag van Wilderen zie onder meer: J. BAERTEN, "Luik en Loon", op. cit., p. 483; Anne-Marie Bonenfant-Feytmans \& Paul Bonenfant, "Du duché de Basse-Lotharingie au duché de Brabant", in Belgisch Tijdschrift voor Filologie en Geschiedenis, dl. 46, 1968, 4, p. 1441-1144; Joseph DARIS, Histoire du diocèse et de la principauté de Liège, depuis leur origine jusqu'au XIII siècle, Luik, Verhoven-Debeur, dl. 1, 1868, p. 488-492; C. GAIER, Art et organisations, op. cit., p. 237-240 en J.-L KUPPER, Liège et l'Église impériale, op. cit., p. 163. 
twaalf dagen een feest rond het landschip hielden ${ }^{(92)}$. Wanneer de Truienaars aanstalten maakten om het landschip verder te laten gaan richting Zoutleeuw, vroeg de graaf van Leuven de stedelingen met aandrang om het landschip niet in zijn territorium te brengen, "opdat ze de vrede niet zouden verbreken, die tussen hen en hijzelf hersteld en met eden bekrachtigd was" (93). De stedelingen gaven echter geen gehoor aan de oproep van de graaf, wat voor deze laatste neerkwam op een oorlogsverklaring en leidde tot een nieuwe inval van de graaf van Leuven in Sint-Truiden en Duras.

In 1140, het derde regeringsjaar van abt Folkard, bezochten de bisschoppen van Luik en Metz, respectievelijk Alberon van Namen en Stefaan van Bar, Sint-Truiden. Bij deze gelegenheid werden de relaties tussen de beide bisschoppen, de abdij en de stadsgemeenschap bekrachtigd in enkele oorkonden. Het gruitrecht en de daarbij horende belastingen op bier werden, zoals hoger besproken, door de bisschop van Metz en met goedkeuring van de bisschop van Luik bevestigd aan de kloostergemeenschap ${ }^{(94)}$. De bisschop van Metz verzekerde de stadsbewoners op hun beurt van tolvrijheid in Metz. De bisschop van Luik trad op als getuige in dit charter, dat publice in villa Sancti Trudonis werd uitgevaardigd ${ }^{(95)}$. Volgens de Gesta maakten de bisschop van Luik en de stedelingen van deze gelegenheid gebruik om - onder goedkeurend oog van de bisschop van Metz - hun eedverbond van onderlinge hulp te hernieuwen ${ }^{(96)}$. Dat hernieuwde eedverbond werd als een fedus pacis et concordie en fedus concordie iuramento omschreven, waardoor de Truienaars vertrouwelingen (fideles) en vrienden (amicos) van de bisschop werden ${ }^{(97)}$. Ook deze keer werd het eedverbond door de graaf van Duras ervaren als een oorlogsverklaring. De graaf vond dat hij als voogd bij dergelijke zaken

(92) Gislebertus Trudonensis, Gesta abbatum Trudonensium, continuatio prima, ed. cit., p. 77-81. Zie ook Paul BONENFANT, "L'épisode de la nef des tisserands de 1135", in Mélanges Félix Rousseau. Études sur l'histoire du pays mosan au Moyen Âge, Brussel, La Renaissance du Livre, 1958, p. 99-109 en R. KüNZEL, Beelden en zelfbeelden, op. cit., p. 162-164. Momenteel bereiden Jeroen Deploige en Walter Simons een nieuwe studie voor over de betekenis van deze passage uit de Gesta.

(93) Gislebertus TRUDONENSIS, Gesta abbatum Trudonensium, continuatio prima, ed. cit., p. 79-80: ut pacem illam, quae inter ipsos et se erat reformata et sacramentis firmata, non infringerent.

(94) Ch. PIot, Cartulaire de l'abbaye, op. cit., dl. 1, nr. 43, p. 56-58.

(95) Ibid., nr. 42, p. 55-56.

(96) Het is onzeker of het eedverbond dateert uit 1140-1141 dan wel uit 1143. De chronologie van de Gesta is op dit gebied onduidelijk. Er wordt tweemaal over een gezamenlijk bezoek van de bisschoppen van Luik en Metz aan Sint-Truiden gesproken. De vraag is of er één dan wel twee gezamenlijke bezoeken van beide bisschoppen onder het abbatiaat van Folkard hebben plaatsgevonden. Vermoedelijk gaat het om één en hetzelfde bezoek in 1140, waarvan de twee bovengenoemde oorkonden getuigen. De continuatio van Sigebert van Gembloers schrijft overigens over een inval van Godfried II van Leuven in Sint-Truiden in 1141, wat te rijmen is met de hypothese dat dit eedverbond in 1140 hernieuwd werd en niet in 1143 . Ten slotte kan men aanvoeren dat het onwaarschijnlijk is dat de gebeurtenissen in 1143 zouden hebben plaatsgevonden, aangezien er expliciet melding wordt gemaakt van de participatie van hertog Godfried van Leuven. In 1143 was Godfried III slechts 3 jaar oud, dus waarschijnlijk bedoelt men Godfried II, die in 1142 om het leven kwam. Continuatio Gemblacensis, ed. L.C. Bethmann, Hannover, Hahn, 1844 (Monumenta Germaniae Historica, Scriptores, dl. 6), p. 387.

(97) Gesta abbatum Trudonensium, continuatio secunda, ed. cit., dl. 2, p. 16-18. 
betrokken had moeten zijn. De hertog van Leuven en de graaf van Namen schaarden zich achter zijn zaak en slaagden erin om de bisschop afstand te laten doen van het verdrag. De legers van de heren van Duras, Leuven en Namen belegerden vervolgens Sint-Truiden en dwongen de stad tot het opstarten van vredesonderhandelingen, waarbij abt Folkard als arbiter (mediator) optrad. Het resultaat was dat de belegering werd stopgezet nadat de stedelingen een boete betaald hadden aan de voogd en beide partijen ook vrede hadden gezworen (iurata pax) $^{(98)}$.

In 1146, ten slotte, een jaar nadat Gerard van Duras abt werd van SintTruiden en in Luik Hendrik II van Leyen aan de macht kwam, verstevigde de nieuwe prinsbisschop met een derde eedverbond in achttien jaar zijn banden met de stedelijke gemeenschap van Sint-Truiden. Hiervan getuigt de oorkonde die eerder al ter sprake kwam en waarin de bisschop aan de stedelingen dezelfde kerkelijke en synodale rechtsgang toekende als aan de Luikenaars. In ruil moesten de Truienaars hun dienstbaarheid (servitium) en trouw (fidelitas) ten opzichte van de Luikse bisschop bevestigen door een eed ${ }^{(99)}$.

In de conflicten met de abdij kwamen de hooggeplaatste stedelingen als individuen tot een oplossing. In de bronnen over de vredes en pacten die gesloten werden met bisschop van Luik of de graaf van Leuven trad de stedelijke gemeenschap als geheel naar voren (oppidani of burgenses Sancti Trudonis) ${ }^{(100)}$. Voortgaand op de getuigenlijsten in de overeenkomsten met bijvoorbeeld de bisschoppen van Metz en Luik in respectievelijk 1140 en 1146, kunnen we ervan uitgaan dat de twee schouten, de villici, de schepenen en de mariscalcus hierbij het voortouw namen: dezelfde lieden dus die in deze decennia in opstand kwamen tegen de abdij en er tegelijkertijd ook gift- en broederschapsrelaties mee onderhielden ${ }^{(101)}$.

Nog meer dan in de conflicten met de abdij, lijkt het zweren van eden een rol te hebben gespeeld in de relaties tussen de Truienaars en de bisschoppen en graven, maar het is duidelijk dat wat enerzijds als een gezworen vrede tussen twee partijen werd gezien, anderzijds door vijanden werd geïnterpreteerd als een provocatie en een uitdaging van de bestaande orde. Ook hier is Oexle's "paradox of conspiracy" dus zeer anwezig ${ }^{(102)}$. Bovendien was dergelijke frontvorming nooit echt duurzaam: wie in het ene conflict een vriend was, werd in het volgende een vijand. Partijvorming werd vooral ingegeven door pragmatisme en opportunisme.

(98) Gesta abbatum Trudonensium, continuatio secunda, ed. cit., dl. 2, p. 16-18.

(99) S. Bormans \& M.L. Polain, Recueil des ordonnances, op. cit., dl. 1, p. 17-18.

(100) Gislebertus TRUdonensis, Gesta abbatum Trudonensium, continuatio prima, ed. cit., p. 74-75 en 79-80; Gesta abbatum Trudonensium, continuatio secunda, ed. cit., dl. 2, p. 16-18 en S. Bormans \& M.L. Polain, Recueil des ordonnances, op. cit., dl. 1, p. $17-18$.

(101) Ch. Piot, Cartulaire de l'abbaye, op. cit., dl. 1, nr. 42, p. 55-56 en S. Bormans \& M.L. Polain, Recueil des ordonnances, op. cit., dl. 1, p. 17-18. Dezelfde personen vinden we als schepenen in andere getuigenlijsten: J.-L. CHARLES, La ville, op. cit., p. 434-435.

(102) O.G. OEXLE, "Peace Through Conspiracy", op. cit., p. 304-307. 


\section{Conclusie}

De casus van Sint-Truiden in de eerste helft van de twaalfde eeuw toont aan dat binnen een kleine verstedelijkende gemeenschap het niet zozeer deze gemeenschap als geheel, maar een beperkte stedelijke elite was die haar eigen positie wist te vrijwaren en te verbeteren door met de regelmaat van de klok in conflict te treden met de abt als stadsheer. Niet het verkrijgen van omvangrijke stadsprivileges, zoals in een aantal Vlaamse steden, of het inrichten van een performante communale organisatie stond op het spel, maar de voortdurend heronderhandelde voorwaarden voor vrede en vriendschap met de lokale machthebber ${ }^{(103)}$. De vriendschaps- en conflictstrategieën van zowel de stedelijke elite als de monniken van Sint-Truiden verschilden niet wezenlijk van die in conflicten tussen rurale elites en religieuze instellingen in de volle middeleeuwen. Door giften, broederschappen of manschap creëerde men nauwe banden met de lokale abdij, maar wanneer men zijn economische of politieke positie in gevaar of beknot zag, voelde men zich genoodzaakt te rebelleren in steeds wisselende allianties.

De stadsbevolking kwam niet alleen in aanvaring met de abt, maar was ook betrokken partij in diverse conflicten met regionale heren. Haar positie in dergelijke conflicten was doorgaans heel wat zwakker, waardoor ze de situatie vaak veeleer diende te ondergaan. Dat verklaart waarom de bevolking zich in de afwikkeling hiervan veel duidelijker als collectief ging opstellen. Niettemin zien we zowel in de lokale discussies tussen elites en abdij, als in de regionale conflicten steeds dezelfde idealen opduiken, waarin pax, amicitia, fidelitas en fraternitas op verschillende niveaus werden beoogd. Als individu of als collectief, als opstandelingen of religieuze schenkers, maar even vaak als slachtoffers van regionaal oorlogsgeweld, zochten de gegoede stedelingen naar een broos evenwicht tussen vriendschap en conflict om hun plek in de samenleving te vrijwaren.

\section{SAMENVATTING}

\section{Ewoud WARNiERS, Amicitia en seditio. Conflictstructuren in de ontwikkeling van de stedelijke autonomie in Sint-Truiden tijdens de eerste helft van de twaalfde eeuw}

Vanaf de volle middeleeuwen trachtten stedelijke groepen meer autonomie te verkrijgen. Hoewel het vaak conflictueuze karakter van de stedelijke emancipatiebeweging niet aan de aandacht van historici ontsnapte, werden tot hiertoe de mechanismen die achter deze conflicten en verzoeningen zaten, nauwelijks onderzocht. In dit artikel worden deze conflictstructuren geanalyseerd aan de hand van een casestudy van de relatief kleine abdijstad Sint-Truiden in de eerste helft van de twaalfde eeuw. De inzet van de conflicten in Sint-Truiden was niet de politieke of juridische macht in de nederzetting. In de conflicten met de abt zien we vooral individuen of facties onder de gegoede stedelingen aan het werk, die directe economische belangen nastreefden van een kleine elite en hierin gesteund werden door lokale feodale heren.

(103) In mijn lopend doctoraatsonderzoek wordt een vergelijkend perspectief tussen de steden in de Luikse regio en enkele Noord-Franse steden uitgewerkt. 
Terzelfdertijd onderhield diezelfde stedelijke elite vriendschapsrelaties met de abt door middel van banden van broederschap of manschap, die bekrachtigd werden door wederzijdse schenkingen. In de conflicten op regionale schaal speelden de Truienaars meer als collectief een rol. Dit is vermoedelijk te wijten aan de zwakkere onderhandelingspositie die de stadsbewoners in deze conflicten hadden. Afhankelijk van de situatie sloot de stadsgemeenschap gezworen vredesovereenkomsten met zowel de prinsbisschop van Luik als de graaf van Leuven. Door het reguleren van vriendschapsrelaties en conflicten met de lokale en regionale machthebbers trachtte de stedelijke elite van Sint-Truiden, die niet in het bezit was van grote vrijheidsprivileges of sterk uitgebouwde communale instellingen, haar positie te verbeteren.

Stadsontwikkeling - conflictbeheersing - stedelijke elite - Sint-Truiden - twaalfde eeuw

\section{RÉSUMÉ}

\section{Ewoud Warniers, Amicitia et seditio. Conflits et développement de l'autonomie urbaine à Saint-Trond durant la première moitié du XII siècle}

Au Moyen Âge central, les ensembles urbains des Pays-Bas méridionaux ont cherché à obtenir une plus grande autonomie. Bien que le caractère conflictuel de l'émancipation urbaine n'ait pas échappé à l'attention des historiens, leurs mécanismes sous-jacents ont à peine été étudiés jusqu'à présent. Dans cet article, ces structures de conflit sont analysées sur la base de l'étude du cas de la relativement petite ville abbatiale de Saint-Trond, dans la première moitié du XII ${ }^{\mathrm{e}}$ siècle. Les enjeux des conflits à Saint-Trond n'étaient pas les libertés politiques ou juridiques dans la ville. Dans ces conflits avec l'abbé, il apparaît surtout qu'agissaient des individus ou des factions parmi les citadins riches de Saint-Trond, poursuivant les intérêts économiques directs d'une petite élite, et soutenus par des seigneurs féodaux locaux. Parallèlement, la même élite urbaine maintenait des relations amicales avec l'abbé par l'intermédiaire d'une fraternité et de serments de fidélité, relations qui étaient confirmées par des dons mutuels. Sur le plan régional, les habitants de Saint-Trond agissaient surtout collectivement dans les conflits car leur pouvoir de négociation individuel était faible. En fonction de la situation, ils conclurent des accords de paix aussi bien avec le prince-évêque de Liège qu'avec le comte de Louvain. Ainsi, en régulant les relations amicales et conflictuelles avec les pouvoirs locaux et régionaux, l'élite de Saint-Trond, qui n'était pas en possession de privilèges de liberté importants ou d'institutions urbaines hautement développées, tenta d'améliorer sa position.

Urbanisation - gestion de conflits - élite urbaine - Saint-Trond - XII ${ }^{\mathrm{e}}$ siècle

\section{ABSTRACT}

Ewoud WARniers, Amicitia and seditio. Conflictual Structures and Urban Emancipation in Sint-Truiden during the First Half of the $12^{\text {th }}$ Century

From the High Middle Ages onwards, urban groups have strived for autonomy. Although the violent character of this urban emancipation movement has duly been accounted for by historians, the mechanisms behind these conflicts and reconciliations 
have hitherto hardly been discussed. In this article, the structures of urban conflicts are analysed by means of a case study: the small town of Sint-Truiden in the first half of the $12^{\text {th }}$ century. The stakes of the conflicts in Sint-Truiden were neither political nor legal autonomy of the city. Clashes with the abbots give evidence of individuals or factions, belonging to an urban elite, targeting direct economic advantages with the support of local feudal lords. These conflicts aside, the urban elite maintained friendly relations with the abbot by means of bonds of fraternity or fealty, which were confirmed by reciprocal gifts. At the level of regional conflicts, the inhabitants of Sint-Truiden were involved as a collective rather than as individuals in view of the townsfolk's weaker position in such conflicts. Depending on the circumstances, the urban community made peace agreements with the prince-bishop of Liège as well as the count of Leuven. By regulating relations of friendship and conflict with local and regional authorities, the urban elite of Sint-Truiden, who wasn't in possession of important freedom charters or well-established institutions, aimed to upgrade its position.

Urbanisation - conflict management - urban elite - Sint Truiden - twelfth century 